\title{
Clinical Performance of Cast Metal and Fiber Post Retained Restorations in Endodontically Treated Teeth: A Systematic Review and Meta-Analysis
}

\author{
Arthur Furtado de Mendonça, Grace M. de Souza, Bianca Furtado de Mendonça, and Ayman Ellakwa
}

\section{ABSTRACT}

Purpose: The purpose of this systematic review was to assess the available literature to evaluate the clinical performance of different post systems for the rehabilitation of endodontically treated teeth (ETT).

Clinical Significance: The loss of structural integrity of endodontically treated teeth usually requires the use of intra-radicular posts for the retention of the final restoration. The recent literature has reported controversial results regarding the clinical performance of different systems.

Material and Methods: An electronic search restricted to the English language was performed up to May 31, 2020. Articles were selected if they met the following criteria: cohort studies and randomized clinical trials comparing the failure rate incidence between fiber and cast metal post, with a mean follow-up of 3 years.

Results: 24 studies (14 cohort studies and 10 RCTs) published between 2000 and 2018 were included in this review. For cast metal posts, 210 cases were classified as failures $(17.07 \%)$, and for fiber posts, 423 were classified as failures $(\mathbf{1 0 . 6 \%})$. An unpaired $t$-test revealed that cast metal and fiber post values were not significantly different $(p=0.58)$ with the difference between means of 5.00 with $95 \%$ confidence of interval (-13.38 to 23.39). Four studies that presented cast metal and fiber posts groups were combined in the metaanalysis. There was no significant difference in the general failure analysis (risk ratio of 0.59 [95\% CI: 0.30 to 1.18$] ; p=0.13$ ).

Conclusions: Based on the present analysis results, the clinical performance of ETT restored with either cast metal- or fiber post-retained restorations presented similar results.

Keywords: Metal post, fiber post, systematic review.
Published Online: December 04, 2021 ISSN: $2684-4443$

DOI: $10.24018 /$ ejdent.2021.2.6.117

Arthur Furtado de Mendonça*

Department of Prosthetic Dentistry, Fluminense Federal University (UFF), Niterói, Brazil.

(e-mail: arthurgsfm ${ }^{\circledR}$ gmail.com)

Grace M. de Souza

Department of Clinical Sciences, University of Toronto, Toronto, Canada.

Bianca Furtado de Mendonça

Department of Prosthetic Dentistry, Gama Filho University (UGF), Rio de Janeiro, Brazil.

Ayman Ellakwa

Oral Rehabilitation \& Dental Materials and Bioengineering, The University of Sydney, Sydney, Australia.

*Corresponding Author

\section{INTRODUCTION}

When the loss of structural integrity caused by caries or deficient existing restorations is associated with the access preparation in endodontically treated teeth (ETT), higher incidence of fractures is observed in non-vital teeth in comparison to vital teeth [1]. Intra-canal posts are recommended to retain the definitive crown restoration of ETT [2]. Cast post and cores have been successfully used for the restoration of pulpless teeth for many years, even though these posts are more rigid than dentin and may increase the risk of unfavorable failures [3]. Cast post and cores also require at least two appointments, temporization, and a laboratory fee. Direct fiber posts have been reported to present advantages over traditional cast post and core for the retention of restorations in ETT. Some of the benefits are reduced treatment time, enhanced esthetics, and reduced stress concentration in the root [4], [5]. Stress concentration is minimized due to the elastic modulus similarity between dentin and fiber posts, reducing the risk of irreversible root fracture [6], [7]. Cast post and cores have higher fracture resistance than fiber posts [3], and the elastic modulus mismatch between the cast metal post and the dentin appears to be a factor responsible for debonding of post and cores from root canals, with potential to increase the risk of root fracture indirectly [8].

Although the lower elastic modulus of a glass fiber post reduces post-debonding risk due to lower stresses at the post/cement interface, when this bonding fails, root stresses in the glass fiber post group were reported to be higher than in the roots restored with cast metal post [9]. However, the glass fiber post restored root would still be less prone to fracture because the fracture risks of the composite core and the post were higher than those of the root [9].

Clinical studies have reported controversial results. While some concluded that direct fiber posts had higher mediumterm survival rates than cast metal posts [10]-[13], other studies showed similar clinical performance between direct fiber and cast metal posts [14]-[17]. Systematic reviews did not show significant differences for the survival rate [4], or 
root fracture incidence between metal and fiber posts [4], [18]. These reviews reported limited included studies and sample sizes, ${ }^{3}$ and high risk of bias in the included studies [18]. Thus, this systematic review aimed to analyze the clinical outcome for teeth restored with cast metal and fiber posts regarding success rate and type of failures, including clinical trials and cohort studies.

\section{METHODS}

A priori registration of this systematic review was included in the international prospective register of systematic reviews (PROSPERO) database (CRD 42019121454).

\section{A. Selection Criteria}

Clinical studies that evaluated the effect of restorative techniques using either fiber-reinforced composite post or custom-made cast metal post on the survival rate of endodontically treated teeth were considered eligible for inclusion in this systematic review from inception to May 2020. Articles were selected if they met the following criteria: cohort studies and randomized clinical trials (RCTs) comparing the failure rate incidence between fiber and cast metal post; cohort and RCTs studies in which one arm reported the outcomes of fiber or cast metal post; mean follow-up period of 3 years.

The exclusion criteria were studies without scientific methodology, study population per arm or cohort of less than 10 patients, simple or systematic reviews, in vitro studies, and studies with a follow-up time of less than 3 years.

\section{B. Search Strategy}

An electronic search restricted to English language was performed in PubMed/MEDLINE, The Cochrane Library (Cochrane Database of Systematic Reviews, Cochrane Central Register of Controlled Trials (CENTRAL), and Web of Science (Science and Social Science Citation Index) up to May 31, 2020. The PICOS searching strategy used is illustrated in Table I. Additionally, a hand search was performed in the list of references of included studies.

\section{Data Extraction and Outcomes}

Two independent reviewers (AFM, BFM) screened the search results and identified studies that were potentially relevant based on titles and abstracts. Relevant studies were selected for full-text analysis according to the eligibility criteria. Disagreement between the 2 reviewers was solved either by consensus or by consulting a third reviewer.

The following data were extracted from the included studies: authors; study design; follow-up period; number of volunteers; number of dropouts; mean age; type of post; type of failure of endodontically treated teeth restored with fiber or cast metal post, including root fracture, dislodgement of the crown, periapical lesions, fracture of the core, loss of cementation, caries and periodontitis; total number of failures, survival of cast post and core, survival of fiber post and composite core.
TABLE I: SySTEMATIC SEARCH STRATEGY (PICOS STRATEGY)

\begin{tabular}{|c|c|}
\hline Population & $\begin{array}{l}\text { \#1 Endodontically treated tooth OR nonvital tooth OR } \\
\text { devitalized tooth OR pulpless tooth. }\end{array}$ \\
\hline Intervention & $\begin{array}{l}\text { \#2 Cast metal post OR metallic post OR carbon-fibre } \\
\text { post OR fibre reinforced composite post OR glass } \\
\text { fibre post OR direct post and core. }\end{array}$ \\
\hline Comparisons & Cast metal post $v s$. fiber-reinforced post. \\
\hline Outcomes & $\begin{array}{l}\text { \#3 Clinical survival OR success OR failure OR } \\
\text { longevity OR long-term OR follow-up OR cohort } \\
\text { studies OR cohort OR controlled clinical trial OR } \\
\text { prospective study [MeSH] OR retrospective study OR } \\
\text { randomized controlled trial. }\end{array}$ \\
\hline Study design & $\begin{array}{l}\text { Randomized controlled trials, controlled clinical trials, } \\
\text { prospective and retrospective cohort studies. }\end{array}$ \\
\hline $\begin{array}{l}\text { Search } \\
\text { combination }\end{array}$ & $\# 1$ and $\# 2$ and \#3 \\
\hline Language & English \\
\hline $\begin{array}{l}\text { Eletronic } \\
\text { databases }\end{array}$ & $\begin{array}{l}\text { PubMed/MEDLINE, Cochrane Central Register of } \\
\text { Controlled Trials and Web of Science }\end{array}$ \\
\hline
\end{tabular}

\section{Quality assessment}

The analysis of cohort studies for the risk of bias was conducted in accordance with the Newcastle-Ottawa scale, and included evaluations of three main categories: selection, comparison, and outcome. For selection, the representativeness of sample size, selection of a comparison group, ascertainment of exposure by secure records and outcome of interest not present in the beginning of the study were evaluated and each study might obtain one point for each item. For the comparability of cohorts on the basis of the design or analysis, two points might be assigned if the study controls for any additional factor (specific control for a second important factor, such as tooth location or residual coronal structure). The assessment of outcome evaluated if there was an independent blind assessment, if the follow-up was long enough for outcomes to occur, and if the subjects lost to follow-up were able to introduce bias. The maximum score assigned to a study was nine points (highest scientific evidence). Studies scoring 6 points and above were regarded as high-quality studies with low risk of bias.

The quality of the study methodology of the included RCTs was assessed using the Cochrane Risk of Bias Tool, using the following criteria: random sequence generation, allocation concealment (selection bias), blinding of participants and personnel (performance bias), blinding of outcome assessment (detection bias), incomplete outcome data (attrition bias), selective reporting (reporting bias), and other bias, which was considered the absence of description regarding the amount of remaining coronal structure or tooth location. The answer for each criterion was reported as low risk, high risk and unclear risk of bias.

\section{E. Data Synthesis and Analysis}

A narrative synthesis of the findings from the included studies is presented, structured around the type of outcome and intervention. The analysis of studies was based on incidence rates, defined as the total number of events per unit of time (i.e., post years) and reflected the probability that a subject would experience the event of interest at a prespecified time [19]. The incidence rate of failures was calculated dividing the number of events by the period of risk of included posts per 1,000 post years of follow-up.

When studies used the same type of intervention, with the 
same outcome measure, the results were pooled using a random-effects meta-analysis, with risk ratios for binary outcomes, and calculated $95 \%$ confidence intervals and twosided $\mathrm{P}$ values for each outcome. Heterogeneity between the studies in effect measures was assessed, when possible, using the $\mathrm{I}^{2}$ statistic. It was considered that an $\mathrm{I}^{2}$ value greater than $50 \%$ was indicative of substantial heterogeneity.

\section{RESULtS}

\section{A. Literature Search and Study Characteristics}

The literature search resulted in 40 manuscripts as potentially relevant to the current analysis, of these 16 were excluded after further detailed assessment. The reasons for exclusion are shown in Fig. 1. Thus, 24 studies (14 cohort studies and 10 RCTs) published between 2000 and 2018 were included in this review [12]-[14], [16], [20]-[39].

The characteristics of the included studies are presented in Tables II to IV. These studies included a total of 5,034 posts, from 3 to 19 years of follow up; 1,156 of those were cast metal posts and 3,904 were fiber posts, and the age of the participants ranged from 36 to 68 years-old.

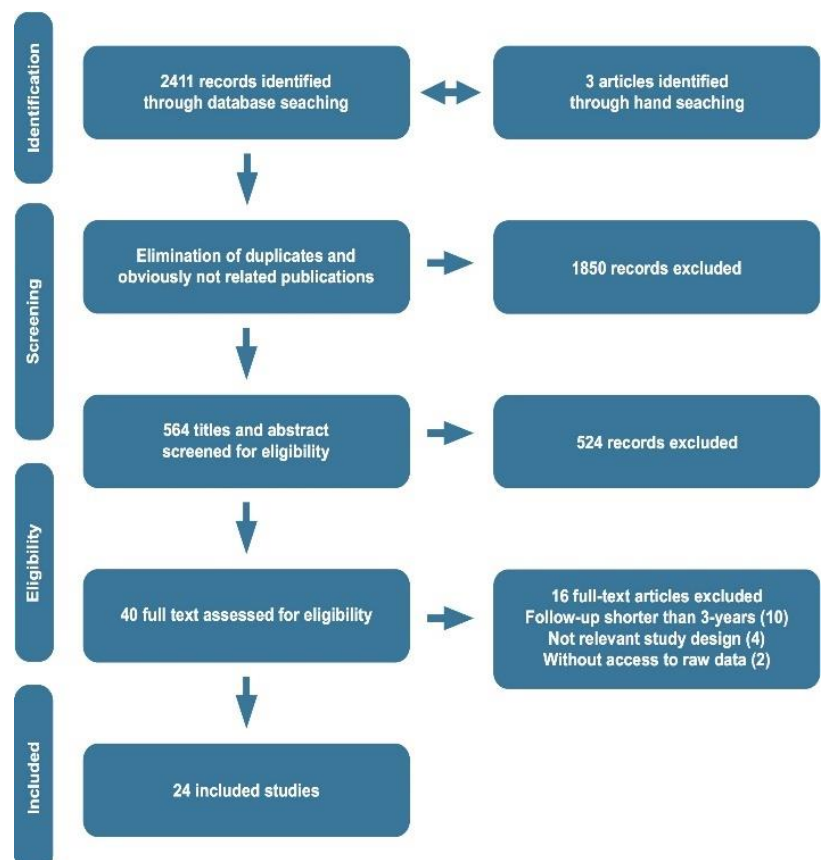

Fig. 1. Search strategy according to PRISMA statement.

TABLE II: MAIN CHARACTERISTICS OF SELECTED STUDIES REPORTING FIBER POST AND CAST METAL POST SYSTEMS.

\begin{tabular}{|c|c|c|c|c|c|}
\hline $\begin{array}{c}\text { Author } \\
\text { (year) }\end{array}$ & $\begin{array}{l}\text { Study design; } \\
\text { mean follow-up }\end{array}$ & $\begin{array}{l}\text { Cast metal post } \\
\text { system (failed/total } \\
\text { restorations) }\end{array}$ & $\begin{array}{c}\text { Fiber post system (failed/total } \\
\text { restorations) }\end{array}$ & $\begin{array}{l}\text { Type of failures for cast } \\
\text { metal post system }\end{array}$ & $\begin{array}{l}\text { Type of failures for } \\
\text { fiber post system }\end{array}$ \\
\hline $\begin{array}{l}\text { Ferrari et al. } \\
{[12]}\end{array}$ & $\begin{array}{l}\text { Retrospective; } \\
4 \text { years }\end{array}$ & $\begin{array}{l}\text { Waxed and cast in } \\
\text { precious alloy } \\
(\text { Medior 3) }(14 / 100)\end{array}$ & $\begin{array}{l}\text { Prefabricated glass fiber post } \\
\text { and resin composite core } \\
\text { (Composipost) }(2 / 100)\end{array}$ & $\begin{array}{l}\text { Periapical lesions (3); root } \\
\text { fracture (9); dislodgement of } \\
\text { the crown (2). }\end{array}$ & Periapical lesions (2). \\
\hline $\begin{array}{l}\text { Creugers et } \\
\text { al. }[16]\end{array}$ & $\begin{array}{l}\text { Controlled } \\
\text { clinical trial; } \\
5 \text { years }\end{array}$ & $\begin{array}{l}\text { Prefabricated cast-on } \\
\text { post and palladium } \\
\text { alloy cast cores } \\
(7 / 127)\end{array}$ & $\begin{array}{l}\text { Prefabricated glass fiber post } \\
\text { (Maillefer) and resin } \\
\text { composite core (Kuraray) } \\
(3 / 150)\end{array}$ & $\begin{array}{l}\text { Root fracture (2); } \\
\text { dislodgment of the restoration } \\
\text { (2); dislodgment with loss of } \\
\text { tooth material (1); tooth loss } \\
\text { (2). }\end{array}$ & $\begin{array}{l}\text { Dislodgment with loss } \\
\text { of tooth material (3). }\end{array}$ \\
\hline $\begin{array}{l}\text { Jung et al. } \\
\text { [39] }\end{array}$ & $\begin{array}{l}\text { Retrospective; } \\
8 \text { years }\end{array}$ & $\begin{array}{l}\text { Gold-platinum alloy } \\
(16 / 41)\end{array}$ & $\begin{array}{l}\text { Tapered or cylindric-tapered } \\
\text { CM (Cendres \& Metaux) and } \\
\text { Mooser posts (Cendres \& } \\
\text { Metaux) }(12 / 31)\end{array}$ & $\begin{array}{l}\text { Root fracture (2); periodontal } \\
\text { failure (6); caries (2); } \\
\text { endodontic failure } \\
\text { dislodgment (1). }\end{array}$ & $\begin{array}{l}\text { Periodontal failure (5); } \\
\text { caries (2); endodontic } \\
\text { failure (4); } \\
\text { dislodgment (1). }\end{array}$ \\
\hline $\begin{array}{l}\text { Cloet et al. } \\
\text { [14] }\end{array}$ & $\begin{array}{l}\text { Controlled } \\
\text { clinical trial; } \\
5 \text { years }\end{array}$ & $\begin{array}{l}\text { Cast gold alloy-based } \\
\text { post and cores } \\
(24 / 101)\end{array}$ & $\begin{array}{l}\text { Prefabricated glass fiber post } \\
\text { (Parapost FibreLux, Coltène- } \\
\text { Whaledent) and resin } \\
\text { composite core (Clear ll AP-X, } \\
\text { Kuraray) (18/91) }\end{array}$ & NR & NR \\
\hline
\end{tabular}

\begin{tabular}{|c|c|c|c|}
\hline Author (year) & Study design; mean follow-up & $\begin{array}{l}\text { Cast metal post system } \\
\text { (failed/total restorations) }\end{array}$ & Type of failures for cast metal post system \\
\hline Fokkinga et al. [21] & $\begin{array}{l}\text { Controlled clinical study; } \\
10 \text { years }\end{array}$ & $\begin{array}{l}\text { Cendres et Métaux } \\
\text { prefabricated cast-on post; } \\
\text { palladium alloy core } \\
(33 / 118)\end{array}$ & $\begin{array}{l}\text { Fracture of restoration (6); dislodgment of post and } \\
\text { crown (7); peri-apical failure (5); periodontal failure } \\
(10) \text {; endodontic failure (1); fracture of the tooth (2); } \\
\text { caries (2). }\end{array}$ \\
\hline Gómez-Polo et al. [22] & Retrospective; 10 years & Cobalt chrome $(15 / 86)$ & NR \\
\hline Hikasa et al. [23] & $\begin{array}{l}\text { Clinical comparative study; } \\
15 \text { years }\end{array}$ & $\begin{array}{l}\text { Gold-silver-palladium alloy } \\
\text { or silver alloy }(72 / 372)\end{array}$ & $\begin{array}{l}\text { Caries (34); tooth fracture (10); endodontic retreatment } \\
\text { (3); marginal periodontitis (9); periapical periodontitis } \\
\text { (12); tooth extraction (4). }\end{array}$ \\
\hline Ernesto et al. [24] & $\begin{array}{l}\text { Retrospective } \\
19 \text { years }\end{array}$ & $\begin{array}{l}\text { Gold alloy type III or Noble } \\
\text { alloy (Ag;Pd;Au) }(29 / 297)\end{array}$ & $\begin{array}{l}\text { Post fracture (14); periodontitis (8); endodontic failure } \\
\text { (3); caries (2); root resorption (1); post dislodgment (1). }\end{array}$ \\
\hline
\end{tabular}




\begin{tabular}{|c|c|c|c|}
\hline Author (year) & $\begin{array}{l}\text { Study design; mean } \\
\text { follow-up }\end{array}$ & $\begin{array}{c}\text { Fiber post system (failed/total } \\
\text { restorations) }\end{array}$ & Type of failures for fiber post system \\
\hline Mannocci et al. [25] & $\begin{array}{l}\text { Clinical study; } \\
3 \text { years }\end{array}$ & $\begin{array}{l}\text { Carbon fiber post (Composipost; RTD) } \\
\text { (7/117). }\end{array}$ & Post dislodgment (3); marginal gaps (4) \\
\hline Naumann et al. [20] & $\begin{array}{l}\text { Prospective; } \\
3.2 \text { years }\end{array}$ & $\begin{array}{l}\text { Tapered fiber post (Luscent Anchors; } \\
\text { Dentatus); Parrallel-sided fiber post } \\
\text { (FiberKor; Jeneric Pentron); and another } \\
\text { tapered fiber post (DentinPost; Komet) } \\
(31 / 149) \text {. }\end{array}$ & $\begin{array}{l}\text { Post fracture (14); loss of retention (9); } \\
\text { root fracture (3); fracture of the core (3); } \\
\text { endodontic failure (2). }\end{array}$ \\
\hline Mannocci et al. [25] & $\begin{array}{l}\text { Randomized } \\
\text { trial; } 5 \text { years }\end{array}$ & $\begin{array}{l}\text { Carbon fibre post (Composipost; RTD) } \\
(15 / 109)\end{array}$ & Caries (15). \\
\hline Segerstrom et al. [13] & $\begin{array}{l}\text { Retrospective; } \\
6 \text { years }\end{array}$ & $\begin{array}{l}\text { Prefabricated carbon fiber reinforced } \\
\text { epoxy resin posts (Composipost) (41/99). }\end{array}$ & $\begin{array}{l}\text { Caries (9); dislodgment of the post (3); } \\
\text { fracture of the teeth (14); periapical } \\
\text { lesions (10); periodontitis (5). }\end{array}$ \\
\hline Ferrari et al. [26] & $\begin{array}{l}\text { Retrospective; } \\
7.5 \text { years }\end{array}$ & $\begin{array}{l}\text { Carbon fibre post (C-Post); quartz fibers } \\
\text { post (Estheti Posts); and Estheti Post Plus } \\
(79 / 1279) .\end{array}$ & $\begin{array}{l}\text { Debonding of the post with dislodgment } \\
\text { of the crown (20); root fracture (1); } \\
\text { fracture of the core (17); partial } \\
\text { debonding of the crown (2); refractory } \\
\text { periapical lesions (39). }\end{array}$ \\
\hline Piovesan et al. [27] & $\begin{array}{l}\text { Longitudinal Clinical } \\
\text { Study; } \\
7.5 \text { years }\end{array}$ & $\begin{array}{l}\text { Ultrahigh molecular weight polyethylene } \\
\text { fiber (Ribbond) (6/109). }\end{array}$ & Post fracture (5); post dislodgment (1). \\
\hline Cagidiaco et al. [28] & $\begin{array}{l}\text { Prospective } \\
3 \text { years }\end{array}$ & $\begin{array}{l}\text { Fiber reinforced composite post (DT } \\
\text { Ligth post; and Everstick customized } \\
\text { fiber reinforced post) }(39 / 240) \text {. }\end{array}$ & Post debonding (39). \\
\hline Signore et al. [29] & $\begin{array}{l}\text { Retrospective } \\
5.3 \text { years }\end{array}$ & $\begin{array}{l}\text { Parallel-sided glass-fiber post (FibreKor } \\
\text { post Pentron); tapered glass-fiber post } \\
\text { (Dentatus) (15/526). }\end{array}$ & $\begin{array}{l}\text { Debonding of post (5); post fracture (1); } \\
\text { fracture of the core (1); fracture of the } \\
\text { crown (5); debonding of the crown (3). }\end{array}$ \\
\hline Ferrari et al. [34] & $\begin{array}{l}\text { Randomized Clinical } \\
\text { Trial; } 6 \text { years }\end{array}$ & $\begin{array}{l}\text { Fiber reinforced composite post (DT } \\
\text { Ligth post; and Everstick customized } \\
\text { fiber reinforced post) }(62 / 209) \text {. }\end{array}$ & $\begin{array}{l}\text { Post debonding (12); endodontic failure } \\
(18) ; \text { post fracture (14); crown } \\
\text { dislodgment (14); root fracture (4). }\end{array}$ \\
\hline Naumann et al. [30] & $\begin{array}{l}\text { Prospective } \\
\text { observational } \\
\text { study; } \\
5.3 \text { years }\end{array}$ & Glass fibre reinforced post (54/149). & $\begin{array}{l}\text { Loss of post retention (17); post fracture } \\
\text { (17) failure of core (3); endodontic } \\
\text { failures (7); root fracture (5); caries (2); } \\
\text { perioendodontic lesions (3). }\end{array}$ \\
\hline Sterzenbach et al. [31] & $\begin{array}{l}\text { Randomized Clinical } \\
\text { Trial; } 3 \text { years }\end{array}$ & $\begin{array}{l}\text { Fiber post (Fiberpoints Root Pins Glass; } \\
\text { Schiutz Dental Group) }(4 / 41) \text {. }\end{array}$ & $\begin{array}{l}\text { Root fracture (2); periodontal failure- } \\
\text { enhance tooth mobility (1); core fracture } \\
\text { (1). }\end{array}$ \\
\hline Parisi et al. [32] & $\begin{array}{l}\text { Retrospective } \\
5.8 \text { years }\end{array}$ & $\begin{array}{l}\text { Quartz fiber post (Ligth-Post; RTD) } \\
(14 / 99) \text {. }\end{array}$ & $\begin{array}{l}\text { Endodontic failure (3); caries } \\
\text { debonding of the post (9). }\end{array}$ \\
\hline Amaral et al. [33] & $\begin{array}{l}\text { Retrospective study; } 3 \\
\text { years }\end{array}$ & $\begin{array}{l}\text { Carbon fiber post and composite core } \\
(2 / 139) \text {. }\end{array}$ & $\begin{array}{l}\text { Endodontic Failure (1); secondary carie } \\
\text { (1). }\end{array}$ \\
\hline Naumann et al [36] & $\begin{array}{l}\text { Randomized clinical } \\
\text { trial; } 11 \text { years }\end{array}$ & $\begin{array}{l}\text { Fiberpoints Root Pins Glass; Schuetz } \\
\text { Dental Group (12/41). }\end{array}$ & $\begin{array}{l}\text { Root fracture (4); core fracture (1); tooth } \\
\text { fracture (1); secondary caries (1); } \\
\text { periodontal failure-enhance tooth } \\
\text { mobility (1); endodontic failure (2); new } \\
\text { restoration due to changes in treatment } \\
\text { planning (2). }\end{array}$ \\
\hline Ferrari et al [37] & Prospective; 7 years & Fber post GC Corp. (46/240). & $\begin{array}{l}\text { Periapical lesion (15); post debonding } \\
\text { (13); post fracture (2); root fracture (16). }\end{array}$ \\
\hline Bergoli et al. [38] & $\begin{array}{l}\text { Randomized Clinical } \\
\text { Trial } 3.1 \text { years }\end{array}$ & $\begin{array}{l}\text { Glass fiber White Post DC System } \\
(9 / 135) \text {. }\end{array}$ & $\begin{array}{l}\text { Root fracture (3); fiber post } \\
\text { decementation (4); core fracture (1); post } \\
\text { fracture (1). }\end{array}$ \\
\hline
\end{tabular}

For cast metal posts, 210 cases were classified as failures (17.07\%). Failures included periodontal failure (45 cases), caries (40 cases), tooth/root fracture (26 cases), endodontic failure (20 cases), fracture of the post (14 cases), dislodgment of crown/post (13 cases), fracture of the crown and tooth loss (6 cases each), root resorption ( 1 case). Two articles did not report the type of failure for cast metal posts (39 cases).

For fiber posts, 423 were classified as failures (10.6\%), and the most common reasons were dislodgment of crown/post (118 cases), endodontic failure (102 cases), fracture of the post (49 cases), tooth/root fracture (55 cases), caries (32 cases), fracture of the core (27 cases), periodontal failure (15 cases), crown fracture (5 cases) and new restoration due to changes in treatment planning ( 2 cases). One study did not report the type of failure for fiber posts (18 cases). 


\section{B. Quality Assessment and Publication Bias}

The risk of bias among cohort studies is shown in Table V. In all cohort studies the sample size was considered representative and exposure was satisfactorily ascertained with data acquired from secure records (medical records), but only 5 studies included a comparison group. For the comparability analysis, four studies included specific control for a second factor (amount of remaining coronal dentin after preparation design), been rated with two stars in this section. In the outcome assessment, eight studies stated an independent blind assessment, and four studies had less than $90 \%$ of the total number of participants assessed in the final examination. Overall, thirteen studies were classified as highquality studies with low risk of bias, scoring 6 or more points.

Regarding the selection and distribution of patients, randomization and allocation concealment were inadequate or unclear for three trials included in this analysis, and two others had an unclear risk for the random sequence generation only. Thereby selection bias was present in five studies since failures in randomization and allocation concealment allow the clinician to predict the upcoming treatment allocation. In addition, for performance and detection, blinding of researches and participants was unclear for all studies. Two studies showed the unclear risk for attrition bias, not presenting well-reported reasons for missing data, or losing follow-up. The remaining coronal walls were also considered bias and was classified as "other" in the analysis. All studies were classified as low risk of bias in this section. The quality assessment of the included trials is shown in detail in Table VI.

TABLE V: QUALITY OF COHORTS USING THE NEW CASTLE - OTTAWA QUALITY ASSESSMENT SCALE

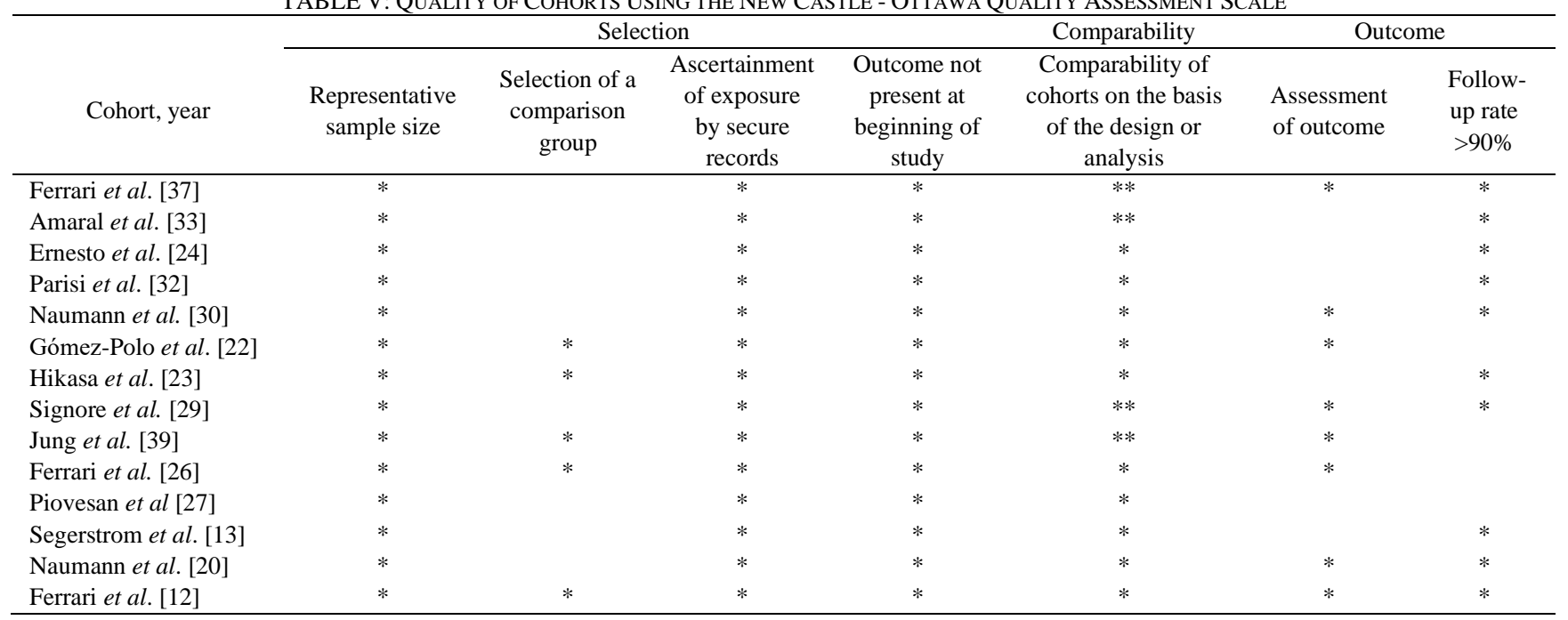

TABLE VI: QUALITY OF RCTS USING COCHRANE RISK OF BIAS TOOL

\begin{tabular}{|c|c|c|c|c|c|c|c|}
\hline & \multicolumn{2}{|c|}{ Selection } & Performance & Detection & Attrition & Reporting & \\
\hline $\begin{array}{c}\text { Randomized clinical } \\
\text { trial, year }\end{array}$ & $\begin{array}{c}\text { Random } \\
\text { sequence } \\
\text { generation }\end{array}$ & $\begin{array}{l}\text { Allocation } \\
\text { concealment }\end{array}$ & $\begin{array}{c}\text { Blinding of } \\
\text { participant and } \\
\text { personnel }\end{array}$ & $\begin{array}{l}\text { Blinding of } \\
\text { outcome } \\
\text { assessment }\end{array}$ & $\begin{array}{c}\text { Incomplete } \\
\text { outcome } \\
\text { data }\end{array}$ & $\begin{array}{l}\text { Selective } \\
\text { reporting }\end{array}$ & Other \\
\hline Bergoli et al. [38] & Low risk & Low risk & Unclear risk & Unclear risk & Low risk & Low risk & Low risk \\
\hline Naumann et al. [36] & Low risk & Low risk & Unclear risk & Unclear risk & Low risk & Low risk & Low risk \\
\hline Cloet et al. [14] & Low risk & Low risk & Unclear risk & Unclear risk & Low risk & Low risk & Low risk \\
\hline Sterzenbach et al. [31] & Low risk & Low risk & Unclear risk & Unclear risk & Low risk & Low risk & Low risk \\
\hline Ferrari et al. 2012 & Unclear risk & Low risk & Unclear risk & Unclear risk & Low risk & Low risk & Low risk \\
\hline Cagidiaco et al. [28] & Unclear risk & Low risk & Unclear risk & Unclear risk & Unclear risk & Low risk & Low risk \\
\hline Fokkinga et al. [21] & Unclear risk & High risk & High risk & High risk & Low risk & Low risk & Low risk \\
\hline Creugers et al. [16] & Unclear risk & Unclear risk & High risk & Unclear risk & Unclear risk & Low risk & Low risk \\
\hline Mannocci et al. [25] & Unclear risk & Unclear risk & High risk & High risk & Low risk & Low risk & Low risk \\
\hline Mannocci et al. [25] & Low risk & Low risk & Unclear risk & Unclear risk & Low risk & Low risk & Low risk \\
\hline
\end{tabular}

\section{Failure Rate Incidence of Post Systems and Meta- analysis}

The failure rate incidence for cast metal posts ranged from 5.13 to 48.78 events per 1,000 post-year, with a mean value of 25.72 and a standard deviation of 16.78 (Fig. 2). For the fiber posts, the rate of failure ranged from 4 to 74.71 events per 1,000 post-year, with a mean value of 30.72 and a standard deviation of 22.84 (Fig. 3). Unpaired $t$ test revealed that the values for cast metal and fiber post were not significantly different $(p=0.58)$ with the difference between means of 5.00 with $95 \%$ confidence of interval $(-13.38$ to 23.39).

Four studies that presented cast metal and fiber posts groups were combined in the meta-analysis (Fig. 4), and there was no significant difference in the general failure analysis (risk ratio of 0.59 [95\% CI: 0.30 to 1.18 ]; $\mathrm{p}=0.13$ ). The heterogeneity among studies was considered substantial $\left(\mathrm{i}^{2}=\right.$ $62 \%, \mathrm{p}=0.05)$. The visual inspection of the funnel plot showed symmetry when the failure of the post system was analyzed, indicating the possibility of no publication bias (Fig. 5). 


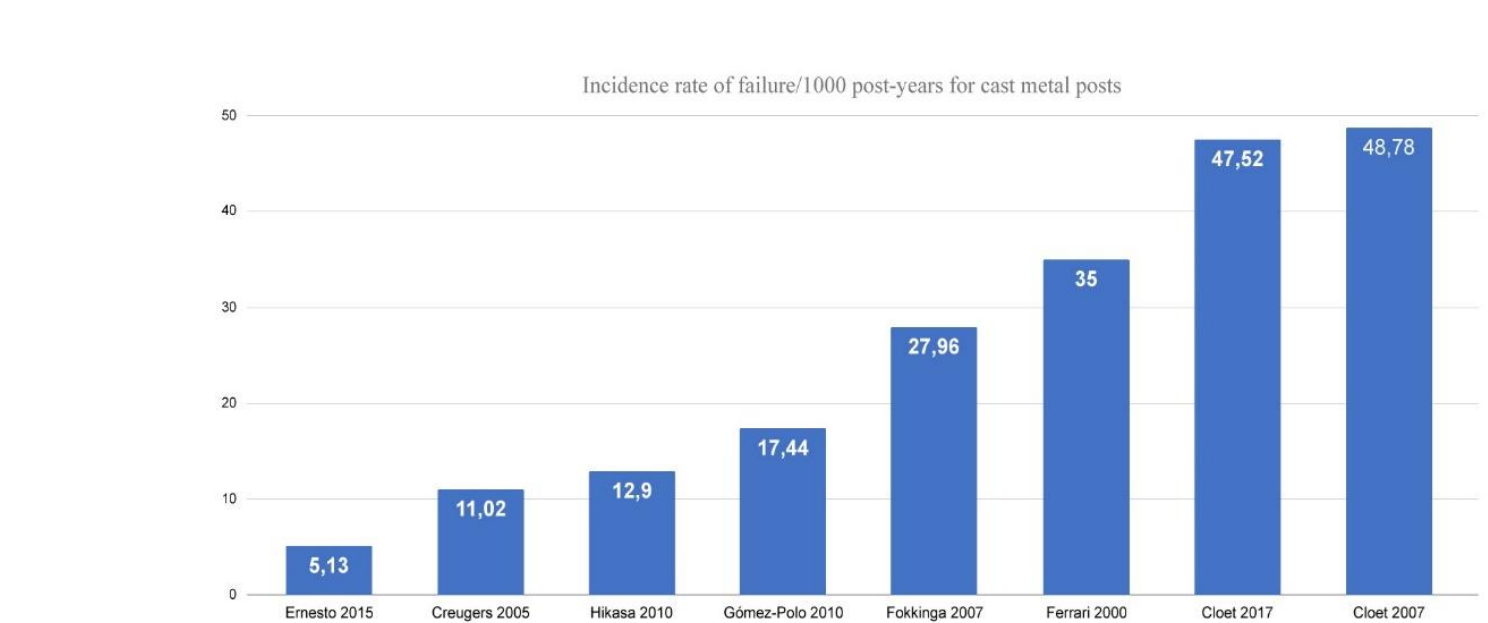

Fig. 2. Incidence rate of failure/1000 post-years for cast metal posts.

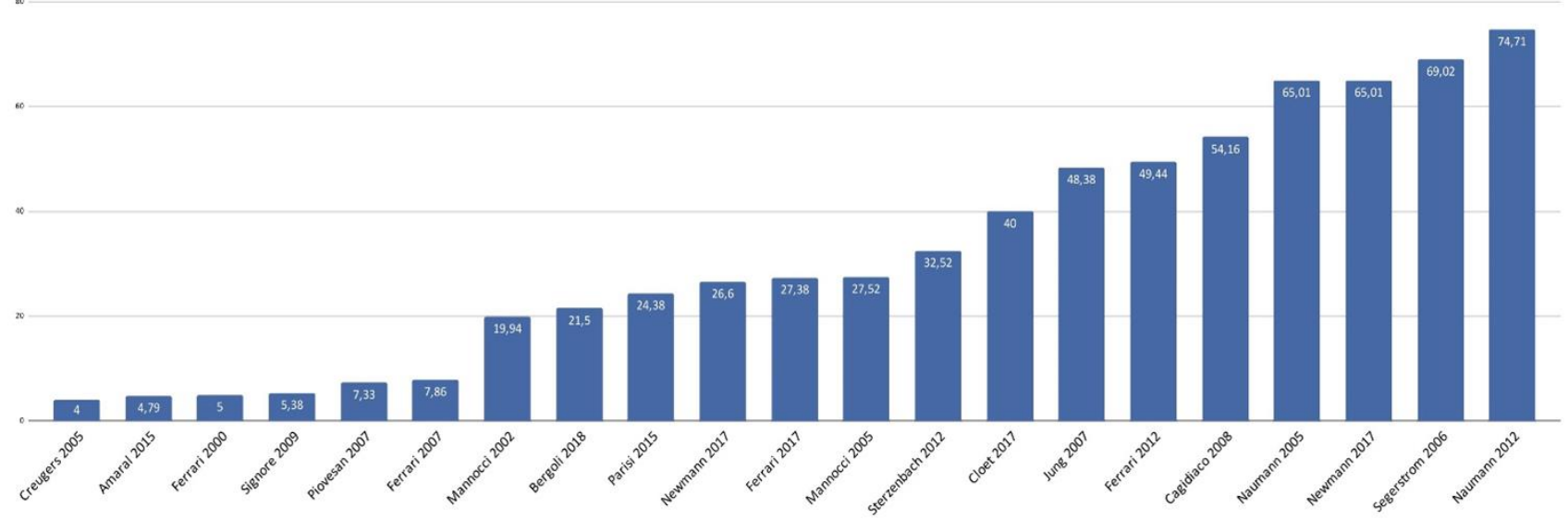

Fig. 3. Incidence rate of failure/1000 post-years for fiber posts.

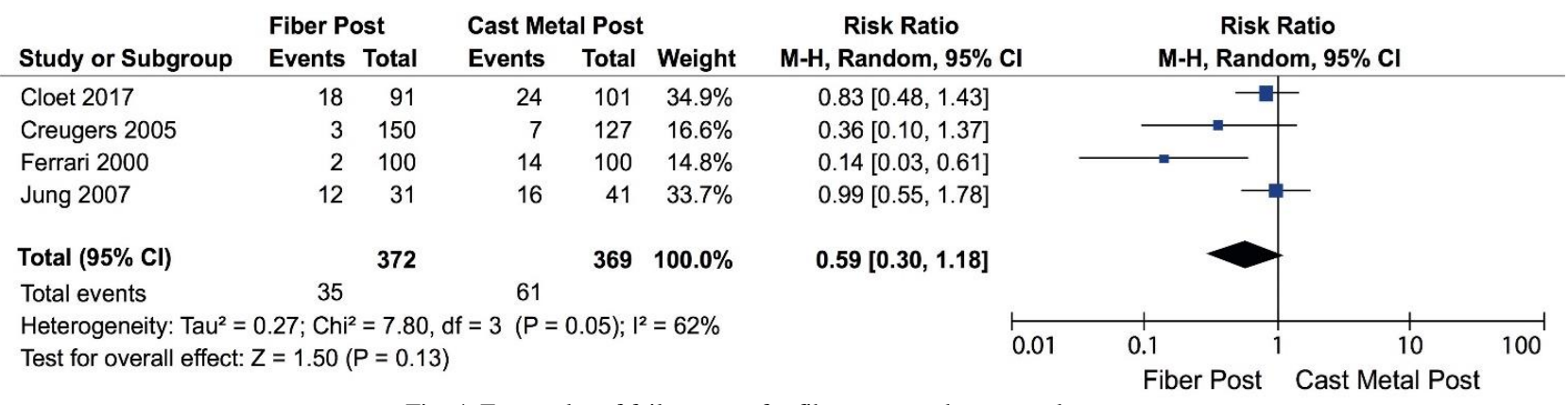

Fig. 4. Forest plot of failure rates for fiber posts and cast metal posts.

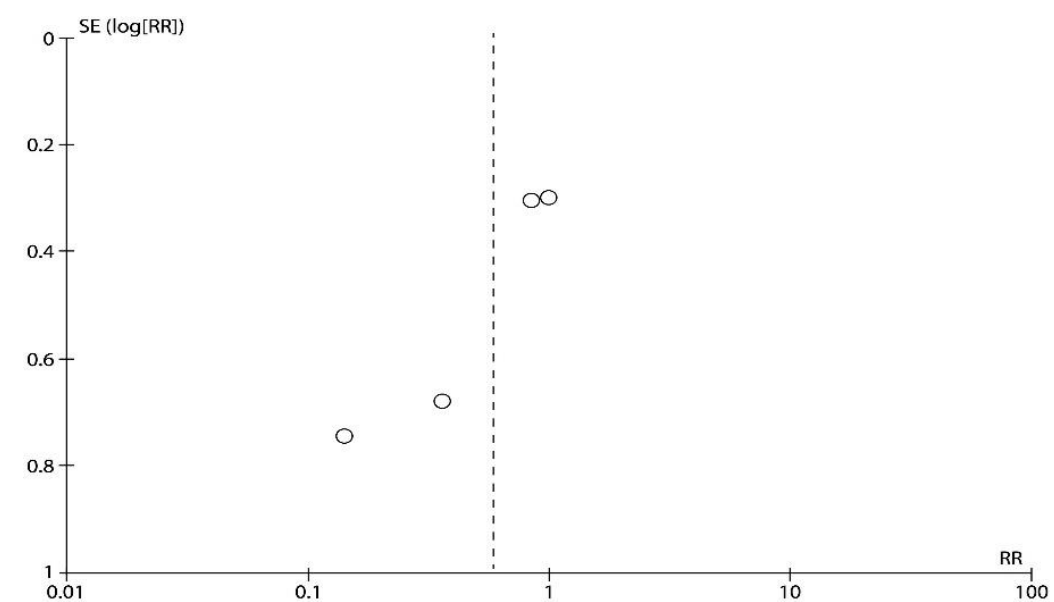

Fig. 5. Funnel chart indicating symmetry between difference in means for studies evaluated. RR, relative risk; SE, standard error. 


\section{DISCUSSION}

The results of this systematic review indicated similar survival rates between cast metal and direct fiber posts. When analyzing the type of failure, dislodgment of the crown/post was the most critical failure for direct fiber posts, while periodontal failures and caries were the most common failures for cast metal posts. Dislodgment of the post can be classified as a relative failure, due to the reversibility of this failure. One example of re-intervention would be shaping the canal for a new intra-canal restoration [40]. Among the failed cast metal posts, it was not possible to relate any of the extractions, as a result from caries, an endodontic or periodontal problem due to malfunctioning of the post-andcore or crown [21].

Studies show that the most serious complication of a postand-core reconstructed tooth is root fracture [41]. One study showed similar incidence of tooth/root fracture for cast metal $(12.62 \%)$ and fiber posts $(13.3 \%)$ [18], indicating that the reduced stress concentration in the root restored with fiber posts demonstrated by in vitro studies did not have a significant effect in clinical performance.

The amount of coronal tooth structure remaining has a direct effect in the survival of endodontically-treated teeth, as shown in many in vitro and in vivo studies [20], [26], [28], [40], [43]. Although a meta-analysis was not possible, the descriptive analysis of the studies included in this review confirmed that assumption: the presence of a ferrule (circumferential dentin collar of at least $2 \mathrm{~mm}$ in height) and the preservation of at least one coronal wall have a direct effect in the strength of the restorative complex. The importance of the remaining tooth structure has already been evidenced in multiple studies showing that when teeth with a substantial amount of remaining dentin were treated with or without posts, the placement of an intra-canal post did not strengthen the tooth or the restorative complex [14], [21].

When the failure rate of anterior and posterior teeth was analyzed, clinical studies reported that intra-canal posts in incisors and canines failed approximately three times more than in premolars or molars [20], [30], [45]. This higher incidence of failure in anterior teeth is due to the higher horizontal forces occurring at their root, making the maxillary anterior region of high-risk for technical failures [45]-[47]. Controversially, two systematic reviews [10], [48], concluded that the failure rates in posterior and anterior teeth treated with post-and-core restorations are similar, but these reviews had limited number of included manuscripts and sample size, with relatively short follow-up periods. More well-designed clinical trials evaluating the survival and failure rates of anterior and posterior teeth treated with postand-core restorations with longer follow-up times are needed.

This systematic review included both clinical trials and observational cohort studies but only a few studies comparing metal and fiber posts were found [21]-[24]. Thus, due to the necessity of more studies for relevant results, the 1-arm design for data analysis was performed. To lower the possible interstudy heterogeneity, only cast metal posts were included, not considering prefabricated metal posts, while direct fiber posts included carbon fiber, quartz fiber and glass fiber. Two included [28], [34] studies compared the survival rate of prefabricated and custom-made fiber posts and reported a higher survival rate for prefabricated fiber posts. A possible explanation for the better performance of this specific type of prefabricated fiber post mentioned in both studies (D.T. Light-Post, Bisco, Inc. Schaumburg, IL, USA) reside in its superior mechanical properties [49], [50]. This may have been an effect of the fiber post manufacturing process, whereby the fibers are prestressed and soaked with resin and released after curing. This technique creates compression around the glass fibers resulting in reduced tensile stresses when the post is exposed to flexural forces [28], [50].

The quality assessment of the included clinical trials demonstrated a high risk of bias but considering that researches and participants could not be blinded during postplacement and follow-up evaluations, this assessment was not considered a key domain. Well, reported random sequence generation, allocation concealment, and loss of follow-up data were found in 5 studies that could be classified as low risk of bias. Overall, fiber and cast metal posts have satisfactory short- and medium-term survival rates. However, well-designed trials with longer follow-up times are needed to provide more information on ETT's clinical performance with intra-canal restorations. Studies evaluating the use of fiber posts in long spam prosthesis with three or four elements are also necessary to establish a clinical protocol for post and core restorations in different clinical challenges.

\section{CONCLUSIONS}

Based on the present analysis results, the clinical performance of endodontically treated teeth restored with either cast metal- or fiber post-retained restorations presented similar results in terms of failure rate.

\section{CONFLICTS OF INTERESTS}

None.

\section{REFERENCES}

[1] Reeh ES. Reduction in tooth stiffness as a result of endodontic restorative procedures. J Endodon, 1989;15:512-6.

[2] Kimmel SS. Restoration of endodontically treated tooth containing wide or flared canal. N Y State Dent J., 2000;66:36-40.

[3] Zhou L, Wang Q. Comparison of Fracture Resistance between Cast Posts and Fiber Posts: A Meta-analysis of Literature. J Endod, 2013;39:11-15.

[4] Boschian PL, Cavalli G, Bertani P, Gagliani M. Adhesive postendodontic restorations with fiber posts: push-out tests and SEM observations. Dent Mater, 2002;18:596-602.

[5] Maccari PC, Conceição EN, Nunes MF. Fracture resistance of endodontically treated teeth restored with three different prefabricated esthetic posts. J Esthet Dent, 2003;15;25-30.

[6] Naumann M, Reich S, Nothdurft FP, Beuer F, Schirrmeister JF, Dietrich T. Survival of glass fiber post restorations over 5 years. Am J Dent, 2008;21:267-72.

[7] Salameh Z, Ounsi HF, Aboushelib MN, Sadig W, Ferrari M. Fracture resistance and failure patterns of endodontically treated mandibular molars with and without glass fiber post in combination with a zirconiaceramic crown. J Dent, 2008;36:513-9.

[8] Ona M, Wakabayashi N, Yamazaki T, Takaichi A, Igarashi Y. The influence of elastic modulus mismatch between tooth and post and core restorations on root fracture. Int Endod J., 2013 Jan;46:47-52.

[9] Santos AF, Meira JB, Tanaka CB, Xavier TA, Ballester RY, Lima RG, Pfeifer CS, Versluis A. Can Fiber Posts Increase root stresses and reduce Fracture? J Dent Res, 2010;89:587-591.

[10] Wang X, Shu X, Zhang Y, Yang B, Jian Y, Zhao K. Evaluation of fiber posts vs metal posts for restoring severely damaged endodontically 
treated teeth: a systematic review and meta-analysis. Quintessence Int. 2019;50:8-20.

[11] Schmitter M, Rammelsberg P, Gabbert O, Ohlmann B. Influence of Clinical Baseline Findings on the Survival of 2 Post Systems: A Randomized Clinical Trial. Int J Prosthodont, 2007;20:173-178.

[12] Ferrari M, Vichi A, Garcia-Godoy F. Clinical evaluation of fiberreinforced epoxy resin posts and cast post and cores. Am J Dent, 2000;13:15B-18B.

[13] Segerstrom S, Astbak J, Ekstrand K. A retrospective long term study of teeth restored with prefabricated carbon fiber reinforced epoxy resin posts. Swed Dent J, 2006;30:1-8.

[14] Cloet E, Debels E, Naert I. Controlled clinical trial on the outcome of glass fiber composite cores versus wrought posts and cast cores for the restoration of endodontically treated teeth: a 5-year follow-up study. Int J Prosthodont, 2017;30:71-9.

[15] Sarkis-Onofre R, Jacinto RC, Boscato N, Cenci MS, Cenci TP. Cast metal vs glass fiber posts: a randomized controlled trial with up to 3 years of follow up. J Dent, 2014;42:582-7.

[16] Creugers NH, Mentink AG, Fokkinga WA, Kreulen CM. 5-year follow-up of a prospective clinical study on Various types of core restorations. Int J Prosthodont, 2005;18:34-9.

[17] Zicari F, Meerbeek BV, Debels E, Lesaffre E, Naert I. An up to 3-year controlled clinical trial comparing the outcome of glass fiber posts and composite cores with gold alloy-based posts and cores for the restoration of endodontically treated teeth. Int $J$ Prosthodont, 2011;24:363-72.

[18] Figueiredo FE, Martins-Filho PR, Faria Silva AL. Do metal postretained restorations result in more root fractures than fiber postretained restorations? A systematic review and meta-analysis. J Endod, 2015;41:309-16.

[19] Koletsi D, Pandis N. introduction to incidence rates and time-changing variables for cohort studies. Am J Orthod Dentofacial Orthop, 2017;152:131-2.

[20] Naumann M, Blankenstein F, Kiessling S, Dietrich T. Risk factors for failure of glass fiber-reinforced composite post restorations: a prospective observational clinical study. Eur J Oral Sci, 2005;113:51924.

[21] Fokkinga WA, Kreulen CM, Bronkhorst EM, Creugers NH. Up to 17year controlled clinical study on post-and-cores and covering crowns. J Dent, 2007;35:778-86.

[22] Gómez-Polo M, Llidó B, Rivero A, Río J, Celemín A. A 10-year retrospective study of the survival rate of teeth restored with prefabricated posts versus cast metal posts and cores. J Dent, 2010;38:916-20.

[23] Hikasa T, Matsuka Y, Mine A, Minakushi H, Hara ES, Meerbeek BV, Yatani H, Kuboki T. A 15-year clinical comparative study of the cumulative survival rate of cast metal core and resin core restorations luted with adhesive resin cement. Int J Prosthodont, 2010;23:397-05.

[24] Ernesto BB, Rosario B, José B. Cast posts: a 44-year retrospective clinical study in a specialized private clinic. Odontoestomatología, 2015;17:11-22.

[25] Mannocci F, Bertelli E, Sherriff M, Watson T, Ford TR. Three-year clinical comparison of survival of endodontically treated teeth restored with either full cast coverage or with direct composite restoration. $J$ Prosthet Dent, 2002;88:297-01.

[26] Ferrari M, Cagidiaco MC, Goracci C, Vichi A, Mason PN, Radovic I, Tay F. Long-term retrospective study of the clinical performance of fiber posts. Am J Dent, 2007;20:287-91.

[27] Piovesan EM, Demarco FF, Censi MS, Cenci TP. Survival rates of endodontically treated teeth restored with fiber-reinforced custom posts and cores: a 97-month study. Int J Prosthodont, 2007;20:151-7.

[28] Cagidiaco MC, Godoy FG, Vichi A, Grandini S, Goracci C, Ferrari M. Placement of fiber prefabricated or custom made posts affects the 3year survival of endodontically treated premolars. Am J Dent, 2008;21:179-84.

[29] Signore A, Benedicenti S, Kaitsas V, Barone M, Angiero F, Ravera G. Long-term survival of endodontically treated, maxillary anterior teeth restored with either tapered or parallel-sided glass-fiber posts and fullceramic crown coverage. J Dent, 2009;37:115-21.

[30] Naumann M, Koelpin M, Beuer F, Lueckel HM. 10-year survival evaluation for glass-fiber-supported postendodontic restoration: a prospective observational clinical study. J Endod, 2012;38:432-35.

[31] Sterzenbach G, Franke A, Naumann M. Rigid versus flexible dentinlike endodontic posts - clinical testing of a biomechanical concept: seven-year results of a randomized controlled clinical pilot trial on endodontically treated abutment with severe hard tissue loss. J Endod, 2012;38:1557-63.

[32] Parisi C, Valandro LF, Ciocca L, Gatto MR, Baldissara P. Clinical outcomes and success rates of quartz fiber post restorations: a retrospective study. J Prosthet Dent, 2015;114:367-72.
[33] Amaral M, Coppo PP, Rosalem CC, Suaid FF, Guerra SM. A 3-year retrospective evaluation of the clinical performance of fiber posts. Braz Dent J, 2015;26:619-23.

[34] Ferrari M, Vichi A, Fadda GM, Cagidiaco MC, Tay FR, Breschi L, Polimeni A, Goracci C. A randomized controlled trial of endodontically treated and restored premolars. J Dent Res, 2012 Jul;91:72S-78S.

[35] Mannocci F, Qualtrough AJE, Worthington HV, Watson TF, Pitt Ford TR. Randomized Clinical Comparison of Endodontically Treated Teeth Restored with Amalgam or with Fiber Posts and Resin Composite: Five-Year Results. Oper Dent, 2005;30:9-15.

[36] Naumann M, Sterzenbach G, Dietrich T, Bitter K, Frankenberger R, Stein-Lausnitz M. Dentin-like versus Rigid Endodontic Post: Elevenyear Randomized Controlled Pilot Trial on No-wall to Two-wall Defects. J Endod, 2017;43:1770-1775.

[37] Ferrari M, Sorretino R, Juloski J, Grandini S, Carrabba, Discepoli N, Cagidiaco E. Post-Retained Single Crowns versus Fixed Dental Prostheses: A 7-Year Prospective Clinical Study. J. Dent. Res, 2017;96:1490-1497.

[38] Bergoli et al. A Multicenter Randomized Double-blind Controlled Clinical Trial of Fiber Post Cementation Strategies. Oper Dent, 2018;43:128-135.

[39] Jung ER, Kalkstein O, Sailer I, Roos M, Hammerle CH. A comparison of composite post buildups and cast gold post-and-core buildups for the restoration of nonvital teeth after 5 to 10 years. Int J Prosthodont, 2007;20:63-9.

[40] Schwindling FS, Tasaka A, Hilgenfeld T, Rammelsberg P, Zenthofer A. Three-dimensional-guided removal and preparation of dental root posts - concept and feasibility. J Prosthodont Res, 2020;64:104-108.

[41] Hatzikyriakos AH, Reisis GI, Tsingos N. A 3-year postoperative clinical evaluation of posts and cores beneath existing crowns. Journal of Prosthetic Dentistry, 1992;67:454-8.

[42] Akkayan B. An in vitro study evaluating the effect of ferrule length on fracture resistance of endodontically treated teeth restored with fiberreinforced and zirconia dowel systems. $J$ Prosthet Dent, 2004;92(2):155-62.

[43] Dietschi D, Duc O, Krejci I, Sadan A. Biomechanical considerations for the restoration of endodontically treated teeth: a systematic review of the literature--Part 1. Composition and micro- and macrostructure alterations. Quintessence Int., 2007 Oct;38:733-43.

[44] Torbjorner A, Fransson B. A literature review on the prosthetic treatment of structurally compromised teeth. Int J Prosthodont, 2004; 17:369-376.

[45] Torbjorner A, Fransson B. Biomechanical aspects of prosthetic treatment of structurally compromised teeth. Int J Prosthodont, 2004; 17:135-41.

[46] Eckerbom M, Magnusson T, Martinsson T. Reasons for and incidence of tooth mortality in a Swedish population. Endod Dent Traumatol, 1992;8:230-4.

[47] Torbjorner A, Karlsson S, Odman PA. Survival rate and failure characteristics for two post designs. J Prosthet Dent, 1995;73:439-44.

[48] Garcia PP, Wambier LM, Geus JL, Cunha LF, Correr GM, Gonzaga CC. Do anterior and posterior teeth treated with post-and-core restorations have similar failure rates? A systematic review and metaanalysis. J Prosthet Dent, 2019 Jun;121:887-894.

[49] Grandini S, Goracci C, Monticelli F, Tay FR, Ferrari M. Fatigue resistance and structural characteristics of fiber posts: three-point bending test and SEM evaluation. Dent Mater, 2005;21:75-82.

[50] Seefeld F, Wenz H-J, Lugwig K, Kern M. Resistance to fracture and structural characteristics of different fiber reinforced post systems. Dent Mater, 2007; 23: 265-71. 